\title{
Expression of a cucumber alanine aminotransferase2 gene improves nitrogen use efficiency in transgenic rice
}

\author{
Atmitri Sisharmini ${ }^{1,2}$, Aniversari Apriana ${ }^{2}$, Nurul Khumaida ${ }^{1}$, Kurniawan Rudi Trijatmiko ${ }^{2}$ and \\ Bambang Sapta Purwoko ${ }^{1 *}$
}

\begin{abstract}
Background: Rice can absorb less than $40 \%$ of applied nitrogen fertilizer, whereas the unabsorbed nitrogen fertilizer may cause environmental problems, such as algal blooms in freshwater and increased production of nitrous oxide, a greenhouse gas which is 300 times more potent than carbon dioxide. Development of nitrogen use efficient (NUE) rice is essential for more environmentally friendly rice production. Recently, NUE rice has been developed by root-specific expression of alanine aminotransferase (AlaAT) gene from barley, a monocot plant. Therefore, we tested the efficacy of AlaAT gene from cucumber in transgenic rice, aiming to provide evidence for the conservation of AlaAT gene function in monocot and dicot.

Results: AlaAT gene from cucumber (CsAlaAT2) has been successfully cloned and constructed on pCAMBIA1300 plant expression vectors under the control of tissue-specific promoter OsAnt1. Agrobacterium tumefaciens-mediated transformation of Indonesian rice cv. Fatmawati using this construct produced 14 transgenic events. Pre-screening of $\mathrm{T} 1$ seedlings grown in the agar medium containing low nitrogen concentration identified selected events that were superior in the root dry weight. Southern hybridization confirmed the integration of T-DNA in the selected event genomes, each of them carried 1, 2, or 3 T-DNA insertions. Efficacy assay of three lead events in the greenhouse showed that in general transgenic events had increased biomass, tiller number, nitrogen content, and grain yield compared to WT. One event, i.e., FAM13, showed an increase in yield as much as $27.9 \%$ and higher plant biomass as much as $27.4 \%$ compared to WT under the low nitrogen condition. The lead events also showed higher absorption NUE, agronomical NUE, and grain NUE as compared to WT under the low nitrogen condition.
\end{abstract}

Conclusions: The results of this study showed that root-specific expression of cucumber alanine aminotransferase2 gene improved nitrogen use efficiency in transgenic rice, which indicate the conservation of function of this gene in monocot and dicot.

Keywords: Alanine aminotransferase, Cucumber, Nitrogen use efficiency, Rice

\section{Background}

Effort to increase rice production in the world must continue to meet the increase in rice demand. The green revolution in 1960-1970 has achieved remarkable increase in rice production. However, the excessive use of fertilizers and pesticides has negative impacts on the environment and soil fertility. The green revolution

\footnotetext{
* Correspondence: bspurwoko@apps.ipb.ac.id

${ }^{1}$ Plant Breeding and Biotechnology Study Program, Departement of Agronomy and Horticulture, IPB University (Bogor Agricultural University), Jl. Meranti, Kampus IPB Darmaga, Bogor 16680, Indonesia

Full list of author information is available at the end of the article
}

and the doubling of food production over the last four decades are associated with an increase in the use of nitrogen fertilizers [10]. The use of nitrogen also rises from 3.5 million tonnes in 1960 to 87 million tonnes in 2000 and is expected to increase to 249 million tonnes by 2050 [32]. The current fertilizer dose of 400 $600 \mathrm{~kg}$ urea/ha commonly used by farmers in Indonesia exceeds the government's recommendation of 200-260 $\mathrm{kg} / \mathrm{Ha}[33]$.

Nitrogen is actively absorbed by plants from the soil in the form of ammonium and nitrate $[2,8,9,21,25]$. 
Nitrogen is an important nutrient used by plants for their growth and development as components of DNA, proteins, enzymes, and metabolite products involved in synthesis and transfer of energy [6, 17]. Nitrates and ammonium are the two inorganic nitrogen compounds existing in agricultural soil and very mobile in the soil. The plant is only capable of using about $30-40 \%$ of the available nitrogen. Thus, more than $60 \%$ of soil nitrogen is lost through a combination of leaching, surface run-off, denitrification, volatilization, and soil microbial consumption. When calculated, $1 \%$ increase in nitrogen use efficiency can save 1.1 billion US dollars per year [15]. Therefore, minimizing $\mathrm{N}$ losses can reduce environmental pollution and reduce production cost.

Among the genes that have been used to improve nitrogen use efficiency in plant is alanine aminotransferase $($ AlaAT) [5, 28]. AlaAT is a pyridoxal-5'-phosphatedependent enzyme found in all parts of the plant. This enzyme activity is not only found in leaves and roots, but also in other tissues such as the endosperm and flower [13]. The pattern of expression of AlaAT shows that this enzyme is involved in important biochemical reactions throughout the plant life cycle. This enzyme catalyzes reversible reaction between pyruvate and glutamate to alanine and 2-oxoglutarat, connecting metabolism of carbon with synthesis of various amino acids [20, 26].

Research on the use of AlaAT gene from barley has been reported on Brassica napus using btg26 rootspecific promoter. Brassica's transgenic plants show an improvement in the nitrogen use efficiency compared to non-transgenic, as indicated by an increase in biomass and seed yield in low $\mathrm{N}$ condition at laboratory and field tests [5]. Heterologous expression of barley AlaAT in transgenic rice has also been conducted using a specific tissue promoter OsAnt1. This modification can increase biomass and grain yield significantly in transgenic rice compared to control plants when the plants are supplied with sufficient nitrogen. Transgenic plants also showed changes in nitrogen content and metabolism significantly. This result indicates the improvement in nitrogen use efficiency [28].

Improvement of $\mathrm{N}$ uptake in cereal plants can be done by manipulating the downstream step in the nitrogen metabolism pathway [28]. The development of food crops that can take and process $\mathrm{N}$ for assimilation more efficiently will make efficient use of $\mathrm{N}$ fertilizer, which can reduce production cost and environmentally friendly [7]. The extensive study on the AlaAT gene to improve nitrogen use efficiency has used the gene from barley that belongs to monocots. Study on the dicots AlaAT genes needs to be initiated to investigate the possible functional conservation of this gene among monocots and dicots and to find orthologous that might be useful for gene optimization purpose in the future.
The objective of this study was to investigate the efficacy of cucumber AlaAT2 gene driven by OsAnt1 rootspecific promoter in improving the nitrogen use efficiency in transgenic rice. Our results indicate that the cucumber AlaAT2 gene can be used for the development of transgenic rice varieties that are efficient in using nitrogen fertilizers.

\section{Methods \\ Generation of plant transformation constructs and transgenic rice}

Fragment encompassing the full-length coding region of CsAlaAT2 was amplified from F1 hybrid cucumber (Cucumis sativus L) cv. Roberto (Chia Tai Seeds Co.) root cDNA. Since the activity of alanine aminotransferase enzyme is induced under hypoxia conditions [4], plant samples were subjected to hypoxia conditions prior to RNA isolation following the procedure described by Kendziorek et al. [16]. Briefly, hypoxia was imposed by submerging roots and shoots of 10-day-old cucumber seedlings up to $1 / 3$ length in flasks containing Yoshida solution covered by about 2-cm layer of oil to prevent gas exchange. Total RNA was isolated from hypoxictreated root using RNeasy Plant Mini Kit as described by the supplier (Qiagen, Germantown, MD, USA). Amplification of CsAlaAT2 gene was performed using a blend of FastStart Taq DNA Polymerase (Roche) and KAPA Hifi DNA Polymerase Hotstart (Kapa Biosystems, Wilmington, MA, USA) and oligonucleotides CsAlaAT2FL-F (5' -gcggatccCGGCTACACCACCAACTCTT-3') and CsAlaAT2-FL-R (5' -gcggtaccTGCACCTTTGATACGCAGGA-3'). The oligonucleotides introduced BamHI and $K p n I$ restriction sites (lowercase) to the amplified fragments at their $5^{\prime}$ and $3^{\prime}$, respectively. OsAnt1 promoter was amplified from genomic DNA of rice cv. Kitaake using FastStart Taq DNA Polymerase and specific oligonucleotides for OsAnt1 promoter [35]. The oligonucleotides introduced HindIII and BamHI restriction sites to the amplified fragments at their $5^{\prime}$ and $3^{\prime}$, respectively. CsAlaAT2 and OsAnt1 fragments were introduced to the pGEM-T Easy vector as described by the manufacturer (Promega, Madison, WI) and subsequently sequenced before digestion and ligation to the binary vector. Promoter and gene fragments with appropriate compatible cohesive ends were ligated together to the HindII-KpnI digested pCAMBIA1300int-prGluA2-GUS-tNOS binary vector [34] as a substitute for GluA2 promoter and GUS gene to create pCAMBIA1300int-prOsAnt1-CsAlaAT2tNOS. The binary vector was transformed into Agrobacterium tumefaciens strain LBA4404 [11] using freeze-thaw method [12]. Transformation of rice cv. Fatmawati (collection of Indonesian Center for Rice Research with accession no. 4825) was performed following the method described by Slamet-Loedin et al. [30]. Briefly, immature 
embryos were co-cultivated with Agrobacterium suspension for 7 days. The elongated shoots were removed, and the embryos were transferred to resting medium. After 5 days, the embryos were transferred to selection medium containing hygromycin and incubated for 10 days. The second selection was performed for 10 days. Embryogenic calli were selected and transferred to fresh selection medium. After 10 days, the resistant calli were transferred to pre-regeneration medium and incubated for 10 days. Proliferating calli with green spots were transferred to regeneration medium. Plantlets were transferred to rooting medium and incubated for 14 days. Direct PCR with leaf disc as template was performed to confirm the presence of CsAlaAT2 transgene in transformed plants using KAPA $3 G$ Plant PCR Kits (Kapa Biosystems) and oligonucleotides CsAlaAT2-F: 5' -ATAAAGCAGAAGGCGCAATG$3^{\prime}$ and tNOS-R: ${ }^{\prime}$-ATTGCCAAATGTTTGAACGA-3'.

\section{Pre-screening of events on agar medium containing low nitrogen concentration}

Pre-screening of events was conducted by germinating T1 seeds of transgenic rice events on agar medium containing macronutrients, micronutrients, and vitamins following Murashige and Skoog [23], except for $\mathrm{NH}_{4} \mathrm{NO}_{3}$ and $\mathrm{KNO}_{3}$ where $1 / 16$ strength was used. Each T1 seed was germinated in a glass test tube (25-mm diameter $\times$ 200-mm height) containing $25-\mathrm{mL}$ agar medium. The seedlings were incubated under continuous light at $28^{\circ} \mathrm{C}$. The seedlings were harvested at 21 days after seeding for evaluation of 6 traits: (1) root length, (2) shoot length, (3) root wet weight, (4) shoot wet weight, (5) root dry weight, and (6) shoot dry weight. The root dry weight was used as the criterion to select the lead events because previous studies show that expression of barley alanine aminotransferase leads to early establishment of a vigorous root system in transgenic rice $[27,28]$.

\section{Molecular characterization}

Five events showing higher root dry weight than control (Table 1) were estimated for the T-DNA insertion number using Southern blot analysis following the method described by Trijatmiko et al. [35]. Briefly, DNA samples were digested with a single-cutter enzyme (EcoRI), separated by agarose gel electrophoresis, denatured, blotted to a nylon membrane, and hybridized with a hygromycin phosphotransferase ( $h p t)$ probe (Fig. 1a). Probe was labeled with DIG-dUTP (Roche), by the method of polymerase chain reaction using oligonucleotides $h p t-\mathrm{F}\left(5^{\prime}\right.$-GCATCT CCCGCCGTGCAC-3') and hpt-R (5'-GATGCCTCCG CTCGAAGTAGCG-3'). Detection was conducted using anti-digoxigenin antibody conjugated to alkaline phosphatase (Roche) and a chemiluminescence substrate (Roche). The light signal was captured on X-ray film (Hyperfilm ECL, GE Healthcare, Chicago, WI, USA).
Table 1 Root and shoot characters of control and transgenic rice plants in MS medium containing 1/16 concentration of nitrogen

\begin{tabular}{|c|c|c|c|c|c|c|}
\hline \multirow[t]{2}{*}{ Line } & \multirow{2}{*}{$\begin{array}{l}\text { Root } \\
\text { length } \\
(\mathrm{cm})\end{array}$} & \multirow{2}{*}{$\begin{array}{l}\text { Shoot } \\
\text { length } \\
(\mathrm{cm})\end{array}$} & \multicolumn{2}{|c|}{ Wet biomass } & \multicolumn{2}{|c|}{ Dry biomass } \\
\hline & & & Root (g) & Shoot (g) & Root (g) & Shoot $(\mathrm{g})$ \\
\hline Control & 11.74 & 33.32 & 0.11 & 0.16 & 0.019 & 0.031 \\
\hline FAM1 & 9.47 & 31.40 & 0.11 & 0.16 & 0.018 & 0.027 \\
\hline FAM2 & 11.17 & 32,90 & 0.11 & 0.17 & 0.019 & 0.032 \\
\hline FAM3 & 9.10 & 33.07 & 0.12 & 0.17 & 0.020 & 0.028 \\
\hline FAM4 & 9.60 & 32.13 & 0.12 & 0.17 & 0.021 & 0.034 \\
\hline FAM5 & $16.37^{*}$ & 32.43 & $0.17^{* *}$ & 0.19 & $0.033^{*}$ & 0.033 \\
\hline FAM6 & 11.33 & 32.53 & 0.11 & 0.17 & 0.017 & 0.025 \\
\hline FAM8 & 8.30 & 22.87 & 0.09 & 0.13 & 0.016 & 0.019 \\
\hline FAM9 & 10.83 & 33.60 & 0.11 & 0.16 & 0.018 & 0.030 \\
\hline FAM10 & 14.07 & 33.13 & 0.10 & 0.17 & 0.014 & 0.027 \\
\hline FAM12 & 11.40 & 29.30 & 0.08 & 0.14 & 0.014 & 0.022 \\
\hline FAM13 & 9.80 & 28.67 & $0.19^{* *}$ & 0.18 & $0.030^{*}$ & 0.033 \\
\hline FAM16 & 9.87 & 32 & 0.093 & 0.183 & 0.016 & 0.025 \\
\hline FAM17 & 9.97 & 32.43 & 0.107 & 0.180 & 0.017 & 0.026 \\
\hline
\end{tabular}

* Significantly higher than control at $P<0.05$

**Significantly higher than control at $P<0.01$

\section{Phenotypic evaluation of transgenic plant}

T1 seeds of three selected events, i.e., FAM3, FAM5, and FAM13, were used for phenotypic evaluation in the greenhouse. Seeds from control plants and transgenic lines were germinated in petri dishes for 2 days and subsequently transferred to germination trays. PCR was conducted on 2-week-old seedlings to select transgenepositive plants. The selected seedlings were transferred to pots for evaluation of nitrogen use efficiency.

Evaluation was conducted in a greenhouse with applied nitrogen treatments following Selvaraj et al. [27], i.e., $\mathrm{N} 0=0 \mathrm{~kg} / \mathrm{ha}, \mathrm{N} 1=90 \mathrm{~kg} / \mathrm{ha}, \mathrm{N} 2=180 \mathrm{~kg} / \mathrm{ha}$, which was converted to the volume of soil in the pot. For N1 and N2, nitrogen was applied in three equal splits at 2 days after transfer (DAT), 10 DAT, and 30 DAT.

Observations were conducted on agronomic characters, including plant height, number of panicle, panicle length, number of filled grain, percent seed set, 1000-grain weight, yield, root dry weight, and shoot dry weight. Root nitrogen concentration and shoot nitrogen concentration were measured by Kjeldahl method [14].

The agronomic data were analyzed by one-way ANOVA implemented in the Statistical Analysis System (SAS Institute Inc., Cary, NC, USA). In the presence of a significant effect for the model source of variation, means separation procedure was used with Fisher's least significant difference at the level of $P=0.05$. The value of absorption NUE (aNUE) was calculated by dividing the total $\mathrm{N}$ absorbed by the plant (gram) by the amount of $\mathrm{N}$ applied (gram). 
a

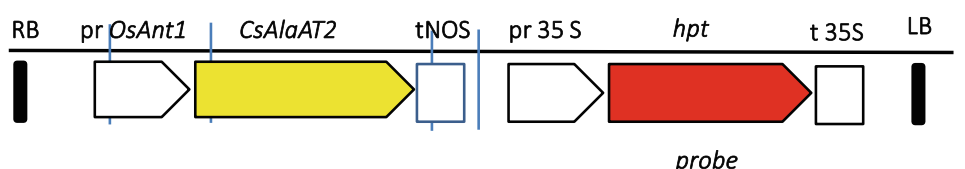

Backbone : pCAMBIA1300int

b

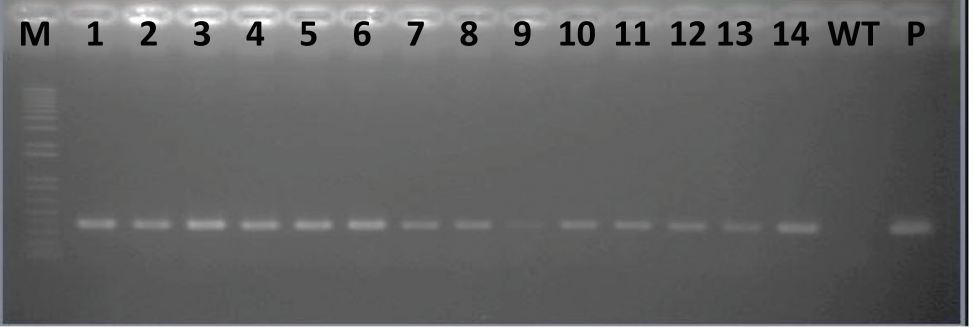

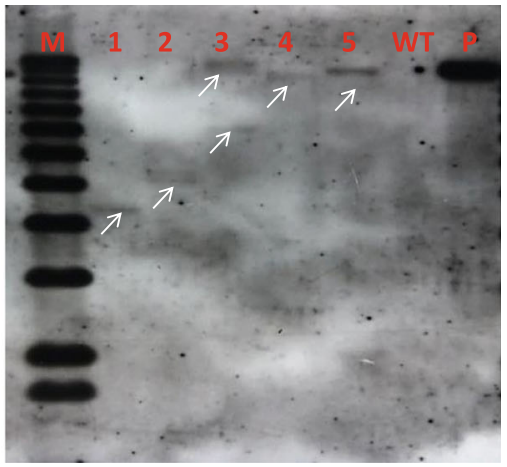

Fig. 1 Development and molecular characterization of CSAlaAT2 transgenic rice event. a Schematic diagram of the T-DNA construct OsAnt1::CSAlaAT2, containing the CSAlaAT2 gene with the NOS terminator under the control of the OsAnt1 promoter. RB, right border; prOsAnt1, promoter antiquitin 1; CSAlaAT2, Cucumis sativus Alanine aminotransferase; tNOS, terminator Nopaline synthase; pr 35 S, promoter 35 S; hpt, hygromycin phosphotransferase; C35S, cauliflower 35 S; LB, left border. b PCR amplification of cucumber AlaAT on T0 transgenic rice lines. M=1 kb DNA ladder plus; $1-14=$ transgenic lines, $W T=$ wild type, $\mathrm{P}=$ plasmid control. c Southern blot analysis showing the copy number of hpt gene insertion in the T0 generation of transgenic lines. Hpt gene insertion is shown by white arrow. $M=$ marker $1 \mathrm{~kb}$ ladder, $W T=$ wild type, $1=\mathrm{FAM} 3$, $2=$ FAM4, $3=$ FAM5, $4=$ FAM 9, 5 = FAM13, P = plasmid of pCAMBIA1301-CSAlaAT2

Agronomic NUE (agNUE) was calculated by dividing the total dry biomass of plant (gram) by the amount of $\mathrm{N}$ applied (gram). Grain NUE (gNUE) was calculated by dividing the yield of plant (gram) by the amount of $\mathrm{N}$ applied (gram) [19, 22].

\section{Results}

\section{Generation of plant transformation constructs and transgenic rice}

PCR product encompassing the open reading frame of CsAlaAT2 gene $(\sim 1.565 \mathrm{~kb})$ has been successfully amplified from cucumber root cDNA, inserted into the pGEM-T easy vector system, and sequenced. The CsAlaAT2 fragment from a correct clone was excised with BamHI and KpnI and ligated together with a HindIIIand BamHI-digested pOsAnt1 fragment into a binary vector pCAMBIA1300int-tNos to produce a plant transformation vector pCAMBIA1300int-pOsAn1t-CsAlaAT2tNos (Fig. 1a). Subsequently, the vector was transformed into the Agrobacterium tumefaciens strain LBA4404 and used for rice transformation. The number of transgenic events created with pCAMBIA1300int-pOsAnt-CsAlaAT2tNos was 14. Confirmation by PCR amplification showed that all 14 events carried CsAlaAT2 transgene (Fig. 1b). Of the positive events, 13 produced at least 200 seeds.

\section{Pre-screening of events on agar medium containing low nitrogen concentration}

T1 plants of 13 selected transgenic rice events (FAMs) were pre-screened on agar medium with low nitrogen. Observation on the 21 days after planting showed that root biomass of 2 transgenic events, i.e., FAM5 and FAM13, were significantly higher than control plant (Table 1).

\section{Molecular characterization of selected events}

Southern blot analysis using EcoRI that cuts only one time in the T-DNA and $h p t$ probe was conducted on 5 selected transgenic T0 events, i.e., FAM3, FAM4, FAM5, FAM9, and FAM13, and wild type. Of the selected events, 3 events (FAM3, FAM9, and FAM13) showed single insertion of T-DNA, 1 event (FAM4) showed 2 insertions of T-DNA, and 1 event (FAM5) showed 3 insertions of T-DNA. As expected, wild-type plant (control) did not show any hybridization (Fig. 1c). The three events with single insertion of T-DNA showed different sizes of bands, indicating that each of them is a unique event.

\section{Phenotypic evaluation of selected events}

Phenotypic evaluation of three selected events, i.e., FAM3, FAM5, and FAM13, was conducted in the greenhouse. T1 
Table 2 Yield parameters measured from greenhouse experiment of three CsAlaAT2 lead events and WT under three N fertilizer regimes

\begin{tabular}{|c|c|c|c|c|c|c|c|}
\hline $\mathrm{N}$ level & Genotype & RDW & SDW & RNC & SNC & $\mathrm{TN}$ & GY \\
\hline \multirow[t]{4}{*}{ N 0\% } & Control (WT) & $4.57^{e}$ & $18.50^{f}$ & 0.06 & $0.14^{c}$ & $7.0^{\mathrm{bc}}$ & $30.59^{\mathrm{bc}}$ \\
\hline & FAM3 & $6.90^{\mathrm{bcd}}$ & $19.95^{\mathrm{def}}$ & 0.10 & $0.22^{b c}$ & $8.3^{\mathrm{ab}}$ & $29.49^{b c}$ \\
\hline & FAM5 & $8.46^{\mathrm{ab}}$ & $23.13^{\text {cdef }}$ & 0.12 & $0.34^{\mathrm{ab}}$ & $8.0^{\mathrm{abc}}$ & $29.11^{b c}$ \\
\hline & FAM13 & $5.33^{\text {cde }}$ & $19.44^{\mathrm{ef}}$ & 0.06 & $0.23^{b c}$ & $9.0^{\mathrm{a}}$ & $34.32^{\mathrm{abc}}$ \\
\hline \multirow[t]{4}{*}{ N 50\% } & Control (WT) & $4.92^{\mathrm{de}}$ & $20.84^{\text {cdef }}$ & 0.08 & $0.20^{b c}$ & $6.3^{b c}$ & $31.48^{\mathrm{bc}}$ \\
\hline & FAM3 & $7.49^{\mathrm{bc}}$ & $24.11^{\mathrm{bcd}}$ & 0.14 & $0.25^{b c}$ & $8.3^{\mathrm{ab}}$ & $37.58^{\mathrm{ab}}$ \\
\hline & FAM5 & $7.38^{\mathrm{bcd}}$ & $20.36^{\text {cdef }}$ & 0.13 & $0.30^{\mathrm{abc}}$ & $8.7^{\mathrm{ab}}$ & $32.62^{a b c}$ \\
\hline & FAM13 & $7.09^{\mathrm{bcd}}$ & $24.69^{b c d}$ & 0.08 & $0.24^{\mathrm{abc}}$ & $9.0^{\mathrm{a}}$ & $40.28^{a}$ \\
\hline \multirow[t]{4}{*}{ N 100\% } & Control (WT) & $5.32^{\text {cde }}$ & $24.51^{\text {bcde }}$ & 0.09 & $0.18^{b c}$ & $7.0^{\mathrm{bc}}$ & $30.55^{\mathrm{bc}}$ \\
\hline & FAM3 & $9.30^{a b}$ & $34.83^{\mathrm{a}}$ & 0.13 & $0.42^{\mathrm{a}}$ & $8.3^{\mathrm{ab}}$ & $33.02^{\mathrm{abc}}$ \\
\hline & FAM5 & $7.28^{\mathrm{bcd}}$ & $25.38^{\mathrm{bc}}$ & 0.09 & $0.27^{\mathrm{abc}}$ & $9.0^{\mathrm{a}}$ & $28.78^{c}$ \\
\hline & FAM13 & $10.13^{\mathrm{a}}$ & $29.27^{b}$ & 0.12 & $0.23^{b c}$ & $9.0^{\mathrm{a}}$ & $34.09^{\mathrm{abc}}$ \\
\hline N level (N) & & * & $* *$ & ns & ns & ns & * \\
\hline Genotype (G) & & * & * & ns & * & $* *$ & * \\
\hline$N \times G$ & & * & * & ns & ns & ns & ns \\
\hline CV (\%) & & 18.59 & 11.37 & 34.31 & 35.50 & 11.08 & 13.32 \\
\hline
\end{tabular}

Means with the same letter are not significantly different

* Significant at $P<0.05$

**Significant at $P<0.01$

plants of selected events and wild type were grown in the pots under 3 different $\mathrm{N}$ dosages, i.e., $0 \mathrm{~kg} / \mathrm{ha}, 90 \mathrm{~kg} / \mathrm{ha}$, and $180 \mathrm{~kg} / \mathrm{ha}$.

The correlation coefficients between traits were calculated and are presented in Table 2. Tiller number was the only trait that showed a positive correlation with grain yield. Tiller number had a positive correlation with root dry weight. Shoot dry weight had positive correlations with root dry weight, root $\mathrm{N}$ concentration, and shoot $\mathrm{N}$ concentration.

Significant differences were detected in $\mathrm{N}$ treatment $(\mathrm{N})$, genotype $(\mathrm{G})$, and $\mathrm{N} \times \mathrm{G}$ interaction for root dry weight and shoot dry weight (Table 3). Significant differences were also detected in genotype $(\mathrm{G})$ for shoot $\mathrm{N}$ concentration, tiller number, and grain yield (Table 3).

Root dry weights of FAM 3 and FAM13 were significantly higher than WT at N $90 \mathrm{~kg} / \mathrm{ha}$, whereas the one in FAM5 was significantly higher than WT at $\mathrm{N} 0 \mathrm{~kg} / \mathrm{ha}$ (Fig. 2a and Table 3). Transgenic plants showed longer and more dense root systems than control plants (Fig. 3). Shoot dry weight of FAM3 was significantly higher than WT at $\mathrm{N} 180 \mathrm{~kg} / \mathrm{ha}$ (Fig. $2 \mathrm{~b}$ and Table 3). Tiller numbers of FAM3 and FAM 13 were significantly higher than WT at $\mathrm{N} 90 \mathrm{~kg} / \mathrm{ha}$ and $\mathrm{N} 180 \mathrm{~kg} / \mathrm{ha}$, whereas the one in FAM5 was significantly higher than WT only at N $90 \mathrm{~kg} / \mathrm{ha}$ (Fig. 2c, Table 3, and Fig. 3). Grain yield of FAM13 significantly outperformed WT at N $90 \mathrm{~kg} / \mathrm{ha}$ (Fig. 2d and Table 3).
All transgenic events showed higher total $\mathrm{N}$ contents than wild type (Table 4). Transgenic events at N $90 \mathrm{~kg} /$ ha showed higher grain NUE than at N $180 \mathrm{~kg} / \mathrm{ha}$ (Table 4). Although in general the increase in $\mathrm{N}$ uptake efficiency of transgenic events at N $180 \mathrm{~kg} / \mathrm{ha}$ was higher than at $\mathrm{N} 90 \mathrm{~kg} / \mathrm{ha}$, but the increase in grain yield of transgenic events at $\mathrm{N} 90 \mathrm{~kg} / \mathrm{ha}$ was in general higher than at $\mathrm{N} 180 \mathrm{~kg} / \mathrm{ha}$ (Table 4).

\section{Discussion}

In our pre-screening experiment, among 13 events evaluated, only 2 events, i.e. FAM5 and FAM13, showed significantly higher root biomass than control plant. This is

Table 3 Correlation among traits (all correlations shown are significant at $P<0.05$ )

\begin{tabular}{lllllllll}
\hline Trait & $\mathrm{PH}$ & $\mathrm{TN}$ & $\mathrm{PL}$ & $\mathrm{GPP}$ & $\mathrm{RDW}$ & $\mathrm{SDW}$ & $\mathrm{RNC}$ & $\mathrm{SNC}$ \\
\hline $\mathrm{TN}$ & - & & & & & & & \\
$\mathrm{PL}$ & - & - & & & & & & \\
$\mathrm{GPP}$ & - & - & - & & & & & \\
$\mathrm{RDW}$ & - & 0.356 & - & - & & & & \\
$\mathrm{SDW}$ & - & - & - & - & $0.636^{* *}$ & & & \\
$\mathrm{RNC}$ & - & - & - & - & $0.553^{* *}$ & 0.368 & & \\
$\mathrm{SNC}$ & - & - & - & - & 0.397 & $0.554^{* *}$ & & \\
$\mathrm{GY}$ & - & $0.449^{* *}$ & - & - & - & - & - & - \\
\hline
\end{tabular}

** Significant at $P<0.001$ 

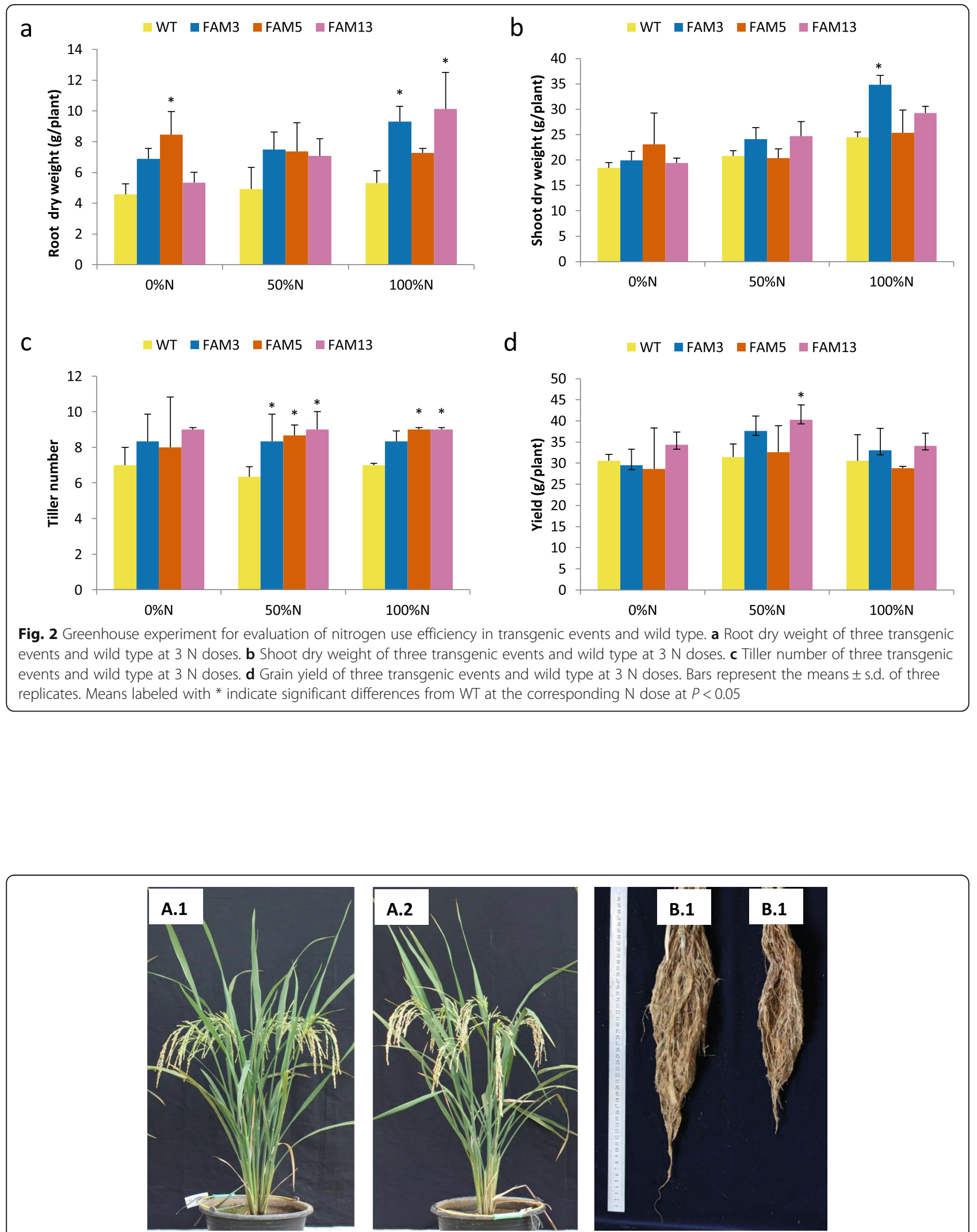

Fig. 3 Performances of $\mathrm{T} 1$ transgenic rice events and $\mathrm{WT}$ at harvest stage at the low $\mathrm{N}$ condition in the greenhouse. $\mathrm{A} 1=$ shoot of event FAM13, $A 2=$ shoot of wild type, B1 = root of event FAM13, B2 = root of wild type 
Table 4 Absorption, agronomic, and grain NUE values in CSAlaAT2 transgenic events

\begin{tabular}{|c|c|c|c|}
\hline \multirow[t]{2}{*}{ Lines } & \multirow[t]{2}{*}{ Character } & \multicolumn{2}{|c|}{$\mathrm{N}$ fertilizer dosage } \\
\hline & & N 50\% & N 100\% \\
\hline \multirow[t]{6}{*}{ Wild type } & Total biomass (gram/hill) & $25.76 \pm 1.99$ & $29.83 \pm 1.19$ \\
\hline & Grain yield/plant (gram/hill) & $31.48 \pm 3.06$ & $30.55 \pm 6.18$ \\
\hline & $\mathrm{N}$ content in plant & $0.28 \pm 0.1$ & $0.27 \pm 0.03$ \\
\hline & Absorption NUE & 0.284 & 0.14 \\
\hline & Agronomical NUE & 25.76 & 14.91 \\
\hline & Grain NUE & 31.48 & 15.28 \\
\hline \multirow[t]{8}{*}{ FAM3 } & Total biomass (gram/hill) & $31.6 \pm 3.36$ & $44.13 \pm 1.36$ \\
\hline & Grain yield/plant (gram/hill) & $37.58 \pm 3.57$ & $33.02 \pm 5.23$ \\
\hline & $\mathrm{N}$ content in plant & $0.39 \pm 0.07$ & $0.56 \pm 0.13$ \\
\hline & Absorption NUE & 0.386 & 0.28 \\
\hline & Agronomical NUE & 31.60 & 22.06 \\
\hline & Grain NUE & 37.60 & 16 \\
\hline & Increase in N uptake efficiency $(\%)^{*}$ & 34.48 & 107.4 \\
\hline & Increase in grain yield $(\%)^{* *}$ & 19.40 & 8 \\
\hline \multirow[t]{8}{*}{ FAM5 } & Total Biomass (gram/hill) & $30.91 \pm 0.88$ & $37.74 \pm 1.33$ \\
\hline & Grain yield/plant (gram/hill) & $33.02 \pm 3.42$ & $30.63 \pm 3.34$ \\
\hline & $\mathrm{N}$ content in plant & $0.43 \pm 0.06$ & $0.36 \pm 0.12$ \\
\hline & Absorption NUE & 0.376 & 0.297 \\
\hline & Agronomical NUE & 30.91 & 18.87 \\
\hline & Grain NUE & 33 & 15.3 \\
\hline & Increase in N uptake efficiency (\%) ${ }^{*}$ & 48.27 & 33.33 \\
\hline & Increase in grain yield $(\%)^{* *}$ & 4.9 & 0.3 \\
\hline \multirow[t]{8}{*}{ FAM13 } & Total Biomass (gram/hill) & $31.78 \pm 4$ & $39.39 \pm 1.45$ \\
\hline & Grain yield/plant (gram/hill) & $40.28 \pm 3.53$ & $34.09 \pm 3.00$ \\
\hline & $\mathrm{N}$ content in plant & $0.32 \pm 0.02$ & $0.35 \pm 0.07$ \\
\hline & Absorption NUE & 0.35 & 0.159 \\
\hline & Agronomical NUE & 31.78 & 19.70 \\
\hline & Grain NUE & 40.2 & 17 \\
\hline & Increase in N uptake efficiency (\%) & 10.34 & 29.63 \\
\hline & Increase in grain yield $(\%)^{* *}$ & 27.95 & 11.58 \\
\hline
\end{tabular}

*Increase in $\mathrm{N}$ uptake efficiency is calculated from the difference between the value of the $\mathrm{N}$ content of transgenic event and control (wild-type) divided by the value of $\mathrm{N}$ content of control line multiplied by $100 \%$

**Increased in the grain yield is calculated from the difference between the results of grain yield/plant of transgenic lines to control (wild-type) divided by grain yield/plant of control line multiplied by $100 \%$

common for genetic engineering to improve specific trait in plant, as shown in Golden Rice 2 [24]. From 619 events developed, only 23 events showed high carotenoid content. Variation among events in the efficacy level is determined by several factors, such as copy number, positional effect, and integrity of T-DNA insert.

Our results indicate that expression of cucumber AlaAT2 in transgenic rice plants under the control of a root-specific promoter (OsAnt1) increased root biomass, tiller number, and grain yield. In comparison with controls, transgenic rice plants showed significant increases in $\mathrm{N}$ content.
Correlation analysis among the traits showed that the only trait that had a positive correlation with grain yield was tiller number. On the other hand, root dry weight was the only trait that had a positive correlation with tiller number. In comparison with controls, transgenic plants showed longer and more dense root systems (Fig. 3), which may be beneficial to the transgenic events because root architecture system has been known to be closely related to the efficiency of nitrogen absorption and is a major determinant for the nitrogen use efficiency $[19,37]$. 
Overexpression of CsAlaAT2 in the root might trigger hypoxic-like response that would stimulate ethylene biosynthesis [1]. Ethylene has been known for its role in promoting root growth and development [3]. In addition, overexpression of AlaAT would increase the use and production of glutamate [1] that has been known for its role in modulating the mitotic activity in the apical meristem $[18,36]$ and the dynamic elongation of root cell files [29].

Root expression of CsAlaAT2 would also produce alanine that is transported to the shoots for usage or storage. In contrast to glutamate, plants do not sense the transport of $\mathrm{N}$ as alanine, which leads to the formation of a positive feedback loop where the plant improves $\mathrm{N}$ uptake and in turn improves $C$ metabolism [1].

We tested three transgenic events in the phenotypic evaluation in the greenhouse. In general, the transgenic events maintained higher tiller number as compared to WT irrespective of $\mathrm{N}$ levels (Fig. 2c). This improvement in tillering capacity might be due to increased $\mathrm{N}$ content in transgenic plants (Table 4). It has been shown previously that each node of rice culm contains a tiller primordium, and tiller formation depends largely on the stored nitrogen and carbohydrates in the culm [31].

Transgenic events showed up to $28 \%$ yield increase compared to WT when grown under limiting N50\%, and lower yield increase (up to 12\%) when grown under N100\%. The capacity of transgenic plants to uptake nitrogen at $\mathrm{N} 100 \%$ is not the limiting factor, because the transgenic events showed higher increase in $\mathrm{N}$ uptake efficiency when grown under $\mathrm{N} 100 \%$ (29.63-107.4\%) as compared to under N50\% (4.9-34.48\%). Instead, this may indicate that $90 \mathrm{~kg} / \mathrm{ha}$ nitrogen (N50\%) is an optimum dose to reach a good balance with the doses of phosphorus and potassium we used in this experiment. It has been shown previously in rice that relationship between $\mathrm{N}$ fertilizer rate and grain yields is not linear [38].

\section{Conclusions}

In summary, we present here the development of transgenic rice plants overexpressing CsAlaAT2 and assessment of the responses of these plants to different levels of supplied N. We identified a transgenic event that had a significantly higher grain yield than wild-type control under $\mathrm{N}$ $90 \mathrm{~kg} / \mathrm{ha}$. The increased yield was correlated with increased tiller number. Transgenic rice plants showed significant increases in nitrogen use efficiency. Our current findings suggest that the cucumber AlaAT2 gene is efficacious to improve nitrogen use efficiency in transgenic rice. Using this gene for large-scale transformation should provide opportunity to identify transgenic rice events which are better in nitrogen use efficiency and, at the same time, have phenotype, nutrient composition, and molecular characteristics that comply with the biosafety regulatory requirements. Cultivating these highly efficacious and clean NUE events will have significant economic and environmental impacts in the rice-based agricultural system.

\section{Abbreviations}

agNUE: Agronomic nitrogen use efficiency; AlaAT: Alanine aminotransferase: ANOVA: Analysis of variance; aNUE: Absorption nitrogen use efficiency; C: Carbon; CDNA: Complementary DNA; CsAlaAT: Cucumis sativus alanine aminotransferase; CSAlaAT2-FL-F: CSAlaAT2-full length-forward; CSAlaAT2-FLR: CSAlaAT2-full length-reverse; DAT: Days after transfer; DIG: Digoxigenin; DW: Dry weight (g); GluA2: Glutelin A2; gNUE: Grain nitrogen use efficiency; GPP: Grains per panicle; GUS: Glucoronidase; GY: Grain yield (g/plant); hptF: Hygromycin phosphotransferase-forward; hpt-R: Hygromycin

phosphotransferase-reverse; MS: Murashige and Skoog; N: Nitrogen; Ns : Not significant; NUE: Nitrogen use efficiency; OsAnt1: Oryza sativa Antiquitin 1; PCR: Polymerase chain reaction; PH: Plant height; PL: Panicle length; RDW: Root dry weight (g); RNA: Ribonucleic acid; RNC: Root N concentration (mg/g DW); SDW: Shoot dry weight (g); SNC: Shoot N concentration (mg/g DW); T-DNA: Transfer-deoxyribonucleic acid; TN: Tiller number; WT: Wild type

\section{Acknowledgements}

We thank Nuryati, H. Hersusatio, M.H. Mubarok, D. Sriyulita, and M.I. Ridwan for technical assistant. We thank Dr. Inez Slamet-Loedin for fruitful discussion

\section{Authors' contributions}

AS conceived the original idea. BSP, KRT, and NK developed the idea. AS and AA performed the experiments. BSP, KRT, and NK supervised the project. AS analyzed the data and wrote the manuscript in consultation with BSP, KRT, and NK. All authors have read and approved the final manuscript.

\section{Funding}

This research was funded by grants from Indonesian Agency for Agricultural Research and Development (Register No. 1798.201.052.A) (to AS), Indonesian Ministry of Agriculture's Scholarship Program (to AS), and SMARTD (Sustainable Management of Agriculture Research and Technology Dissemination) Project (to AS). The funders had no role in the design of the study; in the collection, analysis, and interpretation of data; and in writing the manuscript.

\section{Availability of data and materials}

The datasets generated during and/or analyzed during the current study are available from the corresponding author on reasonable request. The plant seeds generated during the current study have been deposited in the seed bank managed by Indonesian Center for Agricultural Biotechnology and Genetic Resources (ICABIOGRAD) and are available from the Director of ICABIOGRAD on reasonable request with appropriate material transfer agreement and comply with applicable national or international regulation.

Ethics approval and consent to participate

Not applicable.

\section{Consent for publication}

Not applicable.

\section{Competing interests}

The authors declare that they have no competing interests.

\section{Author details}

${ }^{1}$ Plant Breeding and Biotechnology Study Program, Departement of Agronomy and Horticulture, IPB University (Bogor Agricultural University), ال I. Meranti, Kampus IPB Darmaga, Bogor 16680, Indonesia. ${ }^{2}$ Indonesian Center for Agricultural Biotechnology and Genetic Resources Research and Development, J. Tentara Pelajar 3A, Bogor 16111, Indonesia.

Received: 6 September 2019 Accepted: 23 September 2019

Published online: 12 November 2019

\section{References}

1. Beatty PH, Shrawat AK, Carrol RT, Zhu T, Good AG (2009) Transcriptome analysis of nitrogen-efficient rice over-expressing alanine aminotransferase. Plant Biotechnol J. https://doi.org/10.1111/j.1467-7652.2009.00424.x 
2. Dechorgnat J, Nguyen $C T$, Armengaud P, Jossier M, Diatloff E, Filleur $S$, Vedele FD (2011) From the soil to the seeds: the long journey of nitrate in plants. J Exp Bot 6:1349-1359

3. Feng $Y, X u$, , Li B, Wen X, An F, Gong Y, Xin Y, Zhu Z, Wang Y, Guo H (2017) Ethylene promotes root hair growth through coordinated EIN3/EIL1 and RHD6/RSL1 activity in Arabidopsis. PNAS 114(52):13834-13839 https:// doi.org/10.1073/pnas/1711723115

4. Good AG, Crosby WL (1989) Anaerobic induction of alanine aminotransferase in barley root tissue. Plant Physiol 90:1305-1309

5. Good AG, Johnson SJ, De Pauw M, Carrol RT, Savidov N, Vidmar J, Lu Z, Taylor G, Stroeher V (2007) Engineering nitrogen use efficiency with alanine aminotransferase. Can J Bot 85:252-262

6. Hao QN, Zhou XA, Sha AH, Wang C, Zhou R, Chen SL (2011) Identification of genes associated with nitrogen use efficiency by genome-wide transcriptional analysis of two soybean genotypes. BMC Genomics 12(525):1-15

7. Hashimoto M, Herai Y, Nagaoka K, Kouno K (2007) Nitrate leaching in granitic regosol as affected by $\mathrm{N}$ uptake and transpiration by corn. Soil Sci Plant Nutr 53:300-309

8. Haynes RJ, Goh KM (1978) Ammonium and nitrate nutrition of plants. Biol. Rev 53:465-510 https://doi.org/10.1111/j.1469-185X.1978.tb00862.x

9. He X, Qu B, Li W, Zhao X, Teng W, Ma W, Ren Y, Li B, Li Z, Tong Y (2015) The nitrate-inducible NAC transcription factor TaNAC2-5A controls nitrate response and increases wheat yield. Plant Physiol 169(3):1991-2005

10. Hirel B, LeGouis J, Ney B, Gallais A (2007) The challenge of improving NUE in crop plants: toward a more central role for genetic variability and quantitative genetics within integrated approaches. J Exp Bot 58:2369-2387

11. Hoekema A, Hirsch PR, Hooykaas PJJ, Schilperoort RA (1983) A binary plant vector strategy based on separation of vir- and T-region of the Agrobacterium tumefaciens Ti-plasmid. Nature 303:179-180

12. Holsters M, De Waele D, Depicker A, Messens E, Van Montagu E (1978) Transfection and transformation of Agrobacterium tumefaciens. Mol Gen Genet 163:181-187

13. Igarashi D, Miwa T, Seki M, Kobayasi M, Kato T, Tabata S, Shinozaki K, Ohsumi C (2003) Identification of photorespiration glutamate : glyoxylate aminotransferase (GGAT) gene in Arabidopsis. Plant J 33:975-987

14. Jones JB (ed) (1999) Soil analysis handbook of references methods. CRC Press Boca Ratan, London, New York, Washington

15. Kant S, Bi YM, Rothstein S (2011) Understanding plant response to nitrogen limitation for the improvement of crop nitrogen use efficiency. J Exp Bot 62: 1499-1509. https://doi.org/10.1093/jxb/erq297

16. Kendziorek M, Pazkoswski A, Zagdanska B (2012) Differential regulation of alanine aminotransferase homologues by abiotic stresses in wheat (Triticum aestivum L.) seedlings. Plant Cell Rep 31:1105-1117. https://doi.org/10.1007/ s00299-012-1231-2

17. Kusano M, Fukushima A, Redestig H, Saito K (2011) Metabolomic approaches toward understanding nitrogen metabolism in plants. J Exp Bot 62:1439-1453

18. Li Jl, Zhu S, Song X, Shen Y, Chen H, Yu J, Yi K, Liu Y, Karplus VJ, Wu P, Deng XW (2006) A rice glutamate receptor-like gene is critical for the division and survival of individual cells in the root apical meristem. Plant Cell 18(2):340-349

19. Li X, Zeng R, Liao H (2016) Improving crop nutrient efficiency through root architecture modifications. J Integr Plant Biol 58(3):193-202. https://doi.org/ 10.1111/jipb.12434

20. Mc Allister CH, Facette M, Holt A, Good AG (2013) Analysis of the enzymatis properties of a broad family of alanine aminotransferases. PloS One 8(2): e55032. https://doi.org/10.1371/journal.pone.0055032

21. Miller AJ, Fan X, Orsel M, Smith SJ, Wells DM (2007) Nitrate and signalling. J Exp Bot 58:2297-2306

22. Mosier A, Syers JK, Freney JR (2004) Agriculture and the nitrogen cycle. Assessing the impacts of fertilizer use on food production and the enviroment. SCOPE, Washington DC, p 65

23. Murashige T, Skoog F (1962) A revised medium for rapid growth and bio assays with tobacco tissue culture. Physiol Plant 15:473-497

24. Paine JA, Shipton CA, Chaggar S, Howells RM, Kennedy MK, Vernon G, Wright SY, Hinchliffe E, Adam JL, Silverstone AL, Drake R (2005) Improving the nutritional value of golden rice through increased pro-vitamin a content. Nat Biotechnol 23:482-487

25. Rentsch D, Schmidt S, Tegeder M (2007) Transporter for uptake and allocation of organic nitrogen compounds in plants. FEBS Lett 581: 2281-2289
26. Rocha M, Sodek L, Licausi F, Hameed MW, Dornelas MC, Van Dongen JT (2010) Analysis of alanine aminotransferase in various organs of soybean Glycine max and in dependence of different nitrogen fertilizers during hypoxic stress. Amino acid 39:1043-1053. https://doi.org/10.1007/s00726010-0596-1

27. Selvaraj MG, Valencia MO, Ogawa S, Lu Y, Wu L, Down C, Skinner W, Lu Z, Kridl JC, Ishitani M, Van Boxtel J (2016) Development and field performance of nitrogen use efficient rice lines of Africa. Plant Biotechnol J. https://doi. org/10.1111/pbi.12675

28. Shrawat AK, Carrol RT, DePauw M, Taylor GJ, Good AG (2008) Genetic engineering of improved nitrogen use efficiency in rice by the tissuespecific expression of alanine aminotransferase. Plant Biotechnol J 6:722-732

29. Sivaguru Ml, Pike S, Gassmann W, Baskin TI (2003) Aluminum rapidly depolymerizes cortical microtubules and depolarizes the plasma membrane: evidence that these responses are mediated by a glutamate receptor. Plant Cell Physiol 44(7):667-675

30. Slamet-Loedin IH, Chadha-Mohanty P, Torrizo L (2014) Agrobacteriummediated transformation : Rice transformation. In: Henry RJ, Furtado A (eds) Cereal genomic: methods and protocol. Methods in molecular biology, Vol. 1099. Springer, New York, pp 261-271. https://doi.org/10.1007/978-1-62703715-0_21

31. Tanaka A, Garcia CV (1965) Studies of the relationship between tillering and nitrogen uptake of the rice plant. J Soil Sci Plant Nutr 11(3):31-37. https:// doi.org/10.1080/00380768.1965.10431161

32. Tilman D, Fargione J, Wolff B, D'Antonio C, Dobson A, Howarth R, Schindler D, Schlesinger WH, Simberloff D, Swackhamer D (2001) Forecasting agriculturally driven global enviromental change. Science 292:281-284

33. Triadiati AA, Pratama S, Abdurachman (2012) Pertumbuhan dan efisiensi penggunaan nitrogen pada padi (Oryza sativa L.) dengan pemberian pupuk urea yang berbeda. J Anat Physiol 20:1-14 (in Indonesian)

34. Trijatmiko KR, Duenas C, Tsakirpaloglou N, Torrizo L, Arines FM, Adeva C, Balindong J, Oliva N, Sapasap MV, Borrero J, Rey J, Franscisco P, Nelson A, Nakanishi H, Lomzi E, Tako E, Glahn RP, Stangoulis J, Mohanty PC, Johson AAT, Tohme J, Barry G, Slamet-Loedin IH (2016) Biofortified indica rice attains iron and zinc nutrition dietary targets in the field. Sci Rep 6:19792

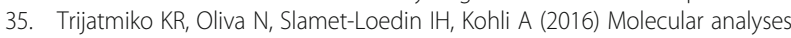
of transgenic plants. Methods Mol Biol 1385:201-222

36. Walch-Liu PI, Liu LH, Remans T, Tester M, Forde BG (2006) Evidence that Lglutamate can act as an exogenous signal to modulate root growth and branching in Arabidopsis thaliana. Plant Cell Physiol 47(8):1045-1057

37. Wang J, Dun X, Shi J, Wang X, Liu G, Wang H (2017) Genetic dissection of root morphology trait related to nitrogen use efficiency in Brassica napus $L$ under two contrasting nitrogen conditions. Front Plant Sci 8:1709

38. Zhang Q, Yang Z, Zhang A, Wang M (2013) Responses of rice (Oryza sativa L.) nitrogen status indicators to nitrogen rates during the different rice growth stages. Adv Mater Res 726-731:4411-4417. https://doi.org/10.4028/ www.scientific.net/AMR.726-731.4411

\section{Publisher's Note}

Springer Nature remains neutral with regard to jurisdictional claims in published maps and institutional affiliations.

\section{Submit your manuscript to a SpringerOpen ${ }^{\circ}$ journal and benefit from:}

- Convenient online submission

- Rigorous peer review

- Open access: articles freely available online

High visibility within the field

- Retaining the copyright to your article

Submit your next manuscript at $>$ springeropen.com 